\title{
Evaluation of the Genotoxicity of Endodontic Materials for Deciduous Teeth Using the Comet Assay
}

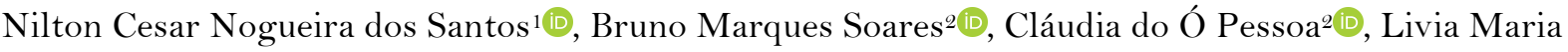 \\ Andrade de Freitas ${ }^{1}{ }^{\circledR}$, João Pedro Pedrosa Cruz ${ }^{1}$, Maria Emília Santos Pereira Ramos ${ }^{3}$, Matheus \\ Melo Pithon ${ }^{1}\left[\right.$, Eneida Moraes de Marcílio Cerqueira ${ }^{4}(\mathbb{0}$
}

\begin{abstract}
'Department of Health, State University of Southwest of Bahia, Jequié, BA, Brazil. ²Department of Pharmacology, Federal University of Ceará, Fortaleza, CE, Brazil. ${ }^{3}$ Department of Health, State University of Feira de Santana, Feira de Santana, BA, Brazil.

${ }^{4}$ Graduate Program in Biotechnology, Department of Biological Science, State University of Feira de Santana, Feira de Santana, BA, Brazil.
\end{abstract}

Correspondence: Matheus Melo Pithon, Av. Otávio Santos, 395, sala 705, Centro Odontomédico Dr. Altamirando da Costa Lima, Bairro Recreio, Vitória da Conquista, BA, Brazil.45020-750. E-mail: matheuspithon@gmail.com

Academic Editor: Catarina Ribeiro Barros de Alencar

Received: 28 March 2020 / Review: 20 July 2020 / Accepted: 11 November 2020

How to cite: Santos NCN, Soares BM, Pessoa CO, Freitas LMA, Cruz JPP, Ramos MESP, Pithon MM, Cerqueira EMM. Evaluation of the genotoxicity of endodontic materials for deciduous teeth using the comet assay. Pesqui Bras Odontopediatria Clín Integr. 202 1; 21 :e0060. https://doi.org/10.1590/pboci.2021.062

\begin{abstract}
Objective: To evaluate genotoxicity of zinc oxide, P. A. calcium hydroxide, mineral trioxide aggregate and an iodoform paste using comet assay on human lymphocytes. Material and Methods: Two positive controls were used: methyl-methanesulfonate for the P.A. calcium hydroxide and mineral trioxide aggregate; and doxorubicin for the iodoform paste and zinc oxide. There were also two negative controls: distilled water for the P.A. calcium hydroxide and mineral trioxide aggregate; and DMSO for the iodoform paste and zinc oxide. Comets were identified using fluorescence microscopy and 100 of them were counted on each of the three slides analyzed per drug test. A damage index was established, taking into consideration the score pattern that had previously been determined from the size and intensity of the comet tail. Analysis of variance, followed by Tukey's test, was used to compare the means of the DNA damage indices. Results: The DNA damage index observed for mineral trioxide aggregate (7.08 to 8.58) and P.A. calcium hydroxide ( 6.50 to 8.33 ), which were similar to negative control index. On the other hand, damage index for zinc oxide (104.7 to 218.50 ) and iodoform paste (115.7 to 210.7) were similar to positive control index. Conclusion: Iodoform paste and zinc oxide showed genotoxicity at all concentrations used.
\end{abstract}

Keywords: Endodontics; Tooth, Deciduous; Mutagenicity Tests; Cells, Cultured. 


\section{Introduction}

Dental caries and dentoalveolar trauma can cause irreversible alterations to dental pulp, culminating in necrosis, which can lead to teeth loss. In view of these changes, pulp therapy is the last resource for deciduous tooth preservation under functional conditions until physiological exfoliation. It should be emphasized that, for successful pulp therapy, appropriate root canal treatment is necessary, using chemicalmechanical preparation along with hermetic filling [1,2].

Among the filling materials for deciduous teeth are used zinc oxide and eugenol paste, iodoform pastes, calcium hydroxide-based paste and mineral trioxide aggregate paste. Although pulp therapy of primary teeth is used for many decades, there is no consensus on the filling paste that could be considered as an ideal material. To deciduous pulp therapy, the paste must be resorbable, provide radiopacity, not interfere with the successor tooth germ's development, and be biocompatible with periapical tissue [1,3-5]. Additionally, it is expected that an ideal filling material does not induce genotoxic and/or cytotoxic effects, but also there's also no consensus on such effects in the studies [6-17].

Genotoxicity of mineral trioxide aggregate (MTA) and calcium hydroxide P.A. (pro-analysis) has not been reported, with no greater occurrence of DNA damage [6,9,12,18,19]. Concerning the potential of products containing zinc oxide or iodoform pastes, there is a scarcity of studies, especially those with the comet methodology. Pires et al. [19] showed that comet assay revealed that iodoform paste did not damage DNA either Guedes Pinto paste, but Santos et al. [12] found genotoxic potential, translated as a higher frequency of micronuclei.

Evaluation of the potential of a product with regard to inducing DNA damage is of great importance, given the relationship between mutagenicity and carcinogenesis [16,17]. Among the tests available for such evaluations include the comet assay [20,21], which has also been used for biomonitoring of individuals or populations when exposed to mutagens [22]. This assay detects single and double stand breaks in DNA molecules caused by alkylating, intercalating and oxidant agents and it can be performed on animal and vegetable cells, both in vitro and in vivo, and it is a methodology that has most often been employed to assessment of the genotoxicity filling pastes [6,9,18,23-26].

The objective of the present study was to evaluate human lymphocytes, using the comet assay, regarding the in vitro genotoxicity of pro-analysis calcium hydroxide (PACH), mineral trioxide aggregate (MTA), zinc oxide and an iodoform paste as recommended by Guedes-Pinto, Paiva and Bozzola [26].

\section{Material and Methods}

Ethical Approval

This research was approved by the Ethics Committee of the Federal University of Ceará, Brazil, under COMEPE-UFC protocol number 281/09.

\section{Chemical Substances}

Four filling paste preparations were used: mineral trioxide aggregate (MTA; Angelus Soluções Odontológicas, Londrina, Brazil); calcium hydroxide P.A. (PACH; Biodinâmica Produtos e Serviços para Laboratórios Ltda, Ibiporá, Brazil) and zinc oxide (ZO; Dentsply, Petrópolis, Brazil). Iodoform paste (IP), in accordance with dental practice, was prepared in the laboratory by mixing equal parts of iodoform (Biodinâmica Produtos e Serviços para Laboratórios Ltda, Ibiporá, PR, Brazil), camphorated paramonochlorophenol (Biodinâmica Produtos e Serviços para Laboratórios Ltda, Ibiporá, PR, Brazil) and an 
ointment composed of $0.15 \%$ rifamycin and $0.5 \%$ prednisolone. Methyl methanesulfonate (MMS) or doxorubicin were used as a positive control and dimethyl sulfoxide (DMSO) or distilled water as a negative control.

\section{Cell Culture}

Heparinized blood (from healthy, non-smoker donors who had not taken any drug at least 15 days prior to sampling) was collected and peripheral blood mononuclear cells (PBMC) were isolated by a standard method of density-gradient centrifugation over Histopaque-1077. PBMC were washed and resuspended in RPMI 1640 medium supplemented with $20 \%$ fetal bovine serum, $2 \mathrm{mM}$ glutamine, $100 \mathrm{U} / \mathrm{mL}$ penicillin, 100 $\mu \mathrm{g} / \mathrm{mL}$ streptomycin at $37^{\circ} \mathrm{C}$ with $5 \% \mathrm{CO}_{2}$. Phytohemagglutinin (3\%) was added at the beginning of culture. After $24 \mathrm{~h}$ of culture, cells were treated with the test compounds.

\section{Test Sample Dilutions}

Two test samples (ZO and IP) in the form of powder and paste respectively were diluted in DMSO and two (PACH and MTA) in the form of powder in distilled water, at the following concentrations: 1:500, 1:750, 1:1000 and 1:2000. The alkylating compound methyl methanesulfonate was the reference for IP and ZO and was used at a concentration of $0.4 \mu \mathrm{M}$ diluted in distilled water $(\mathrm{v} / \mathrm{v})$. Doxorubicin was used as a positive control for HPCH and MTA, at a concentration of $0.6 \mu \mathrm{M}$ diluted in DMSO at $0.1 \%(\mathrm{v} / \mathrm{v})$.

\section{Comet Assay}

The comet assay, used to detect DNA strand breaks, was conducted under alkaline conditions as described by Singh et al. [20] with minor modifications [27] and following the recommendations of the International Workshop on Genotoxicity Test Procedures [22]. At the end of the treatment, PBMC were washed with ice-cold PBS, trypsinized with $100 \mu \mathrm{L}$ trypsin $(0.15 \%)$ and resuspended in a complete RPMI medium. Then, $20 \mu \mathrm{L}$ of cell suspension $(\sim 106$ cells $/ \mathrm{mL})$ were dissolved in $0.75 \%$ low melting point agarose and immediately spread onto a glass microscope slide precoated with a layer of $1 \%$ normal melting point agarose. The slides were incubated in lysis solution $(2.5 \mathrm{M} \mathrm{NaCl}, 10 \mathrm{mM}$ Tris, $100 \mathrm{mM}$ EDTA, $1 \%$ Triton X100 and $10 \%$ DMSO, $\mathrm{pH}=10.0)$ at $4{ }^{\circ} \mathrm{C}$ for a minimum of $1 \mathrm{~h}$. After then, they were placed on a horizontal electrophoresis unit filled with fresh buffer $\left(300 \mathrm{mM} \mathrm{NaOH}\right.$ and $1 \mathrm{mM}$ EDTA, pH >13.0) for 20 min at $4{ }^{\circ} \mathrm{C}$ to allow DNA unwinding and expression of alkali-labile sites. Electrophoresis was conducted for 20 min at $25 \mathrm{~V}$ and $300 \mathrm{~mA}(0.86 \mathrm{~V} / \mathrm{cm})$. Each slide was stained with $50 \mu \mathrm{L}$ of ethidium bromide $(20 \mu \mathrm{g} / \mathrm{mL})$ and covered with a coverslip. The cells' analysis was performed by a visual scoring system using an epifluorescence microscope (Olympus, Tokyo, Japan) with an excitation filter of 510-560 $\mathrm{nm}$ and a barrier filter of $590 \mathrm{~nm}$ at $400 \mathrm{x}$ magnification [28].

Three hundred randomly selected cells (100 cells from each of the three replicate slides) were analyzed for each concentration of test substance. Cells were scored visually according to tail length into five classes: (1) class 0: undamaged cells having no tail; (2) class 1: cells having a tail shorter than the diameter of the head (nucleus); (3) class 2: cells having a tail length 1-2 times the diameter of the head; (4) class 3: cells having a tail longer than 2 times the diameter of the head; (5) class 4: comets having no heads. For the data analysis, the slides were coded; decoding was done after genotoxicity determination by one (single) experienced blinded investigator standardized with the team of the Toxicological Genetics Laboratory of the Federal University of Ceará. 
Statistical Analysis

A value (damage index, DI) was assigned to each comet according to its class, using the formula: DI = $(\mathrm{O} \times \mathrm{no})+(1 \times \mathrm{n} 1)+(2 \times \mathrm{n} 2)+(3 \times \mathrm{n} 3)+(4 \times \mathrm{n} 4)$, where $\mathrm{n}=$ number of cells in each class analyzed. Damage index thus ranged from 0 (completely undamaged: 100 cells $\times 0$ ) to 400 (with maximum damage: 100 cells $\times$ 4). The damage frequency (DF) represents the percentage of cells that suffered DNA damage. For statistical analysis on the experiments, ANOVA and Tukey test were used in the Prisma software, version 6.0 (GraphPad Prism Software). Results were considered to be statistically significant when $\mathrm{p}<0.05$.

\section{Results}

Table 1 presents the average rate of DNA damage (DR) and their mean standard error (SEM) found for the test samples of negative and positive controls: distilled water and methyl methanesulfonate (MMS), respectively; calcium hydroxide P.A. (PACH) and mineral trioxide aggregate (MTA). Statistical analysis revealed no significant differences between the mean values obtained in the different concentrations of the test samples and negative controls, which were significantly lower than that calculated for the positive control.

Table 1. Data on average rate of DNA damage (DR), and their mean standard error (SEM).

\begin{tabular}{lcc}
\hline \multicolumn{1}{c}{ Samples } & Treatment & DR \pm SEM $^{\mathrm{a}}$ \\
\hline Distilled Water & $0.4 \mu \mathrm{M}$ & $5.66 \pm 0.73^{\mathrm{a}}$ \\
Methyl Methane Sulfonate & $1: 500$ & $178.75 \pm 5.90^{\mathrm{b}}$ \\
P. A Calcium Hydroxide & $1: 750$ & $6.83 \pm 1.00^{\mathrm{a}}$ \\
& $1: 1000$ & $8.33 \pm 0.84^{\mathrm{a}}$ \\
& $1: 2000$ & $7.91 \pm 0.99^{\mathrm{a}}$ \\
Mineral Trioxide Aggregate & $1: 500$ & $6.50 \pm 1.09^{\mathrm{a}}$ \\
& $1: 750$ & $7.66 \pm 0.87^{\mathrm{a}}$ \\
& $1: 1000$ & $8.58 \pm 0.89^{\mathrm{a}}$ \\
& $1: 2000$ & $7.58 \pm 0.98^{\mathrm{a}}$ \\
\hline Different letters in the same column, the treatments differ significantly by Tukey test $(\mathrm{p}<0.05)$.
\end{tabular}

Table 2 presents the average rates of DNA damage (ID) and standard error of the mean (SEM) calculated for the test samples of negative and positive controls: dimethylsulfoxide (DMSO) and doxorubicin (DOX), respectively; zinc oxide $(\mathrm{ZO})$ and Iodoform Paste, respectively. Statistical analysis revealed that the mean levels of DNA damage obtained from the treatment of test samples (ZO and IP) were significantly higher than the negative control and positive control did not differ from average.

Tabela 2. Data on average rate of DNA damage (DR), and their mean standard error (SEM).

\begin{tabular}{lcc}
\hline \multicolumn{1}{c}{ Samples } & Treatment & DR \pm SEM $^{\mathrm{a}}$ \\
\hline DMSO & $0.1 \%(\mathrm{v} / \mathrm{v})$ & $14.00 \pm 0.57^{\mathrm{a}}$ \\
Doxorubicin & $0.6 \mu \mathrm{M}$ & $145.7 \pm 32.33^{\mathrm{b}}$ \\
Zinc Oxid & $1: 500$ & $218.5 \pm 7.57^{\mathrm{b}}$ \\
& $1: 750$ & $204.0 \pm 13.20^{\mathrm{b}}$ \\
& $1: 1000$ & $143.5 \pm 12.14^{\mathrm{b}}$ \\
Iodoform Paste & $1: 2000$ & $104.7 \pm 9.33^{\mathrm{b}}$ \\
& $1: 500$ & $210.7 \pm 30.57^{\mathrm{b}}$ \\
& $1: 750$ & $153.5 \pm 26.12^{\mathrm{b}}$ \\
& $1: 1000$ & $123.3 \pm 9.68^{\mathrm{b}}$
\end{tabular}

Different letters in the same column, the treatments differ significantly by Tukey test $(\mathrm{p}<0.05)$. 


\section{Discussion}

The present study evaluated the genotoxicity of filling pastes for deciduous tooth pulpectomy that is a matter of great relevance for pediatric dentistry when analyzing the relation of the product regarding the mutagenic potential. The paste options currently available are iodoform-based, calcium hydroxide-based, zinc oxide-based (with or without eugenol) and mineral trioxide aggregate-based [29,30]. These products were investigated in the present study due to their use in dental practice and the scarcity of studies in the literature addressing these substances' genotoxic potential. This study used the comet assay to access the genotoxic potential of filling pastes. This is a sensitive and quick method that is able to detect DNA injuries in individual cells through direct measurement [31,32]. This method has been used with some frequency to evaluate the genotoxicity of cements and root canal filling pastes currently used in pulp therapy. This study revealed that zinc oxide, tested alone without eugenol and iodoform paste was genotoxic at all tested concentrations. In the literature, Pires et al. [19] inferred the same to the iodoform paste; however, Santos et al. [12] found different result and verified that these pastes (IP and OZ) both showed genotoxicity, translated like micronuclei, and cytotoxicity expressed by relation polychromatic erythrocyte and normochromic erythrocytes (PCE/NCE).

Regarding zinc oxide, some studies also performed comet assay on human lymphocytes, but the dental filling products tested were zinc oxide-based cement with and without eugenol and not the pure paste tested used in our study. Moreover, the treatments were different, such that these authors used lower concentrations. Under these conditions, they concluded that the substances evaluated presented "acceptable biocompatibility in terms of genotoxicity" $[8,25,33]$.

Conflicting results regarding zinc oxide's genotoxicity have been reported in studies in which the endpoints analyzed were chromosome damage [25,33]. While Hikiba et al. [33] observed a greater occurrence of chromosome aberrations in embryonic hamster cells in the cultures treated, Brzovic et al. [25] did not report any greater occurrence of these aberrations in cultures of human lymphocytes treated with zinc oxidebased cement and eugenol. Evaluating chromosome damage translated by micronuclei, Camargo et al. [8] did not report any greater occurrence of these structures in fibroblasts from Chinese hamsters that were treated with cement-based on this substance.

No genotoxic effects from iodoform were reported by Hikiba et al. [33]. Such effects would have been translated through greater occurrence of chromosome aberrations in embryonic Chinese hamster cells. The results obtained by Hagiwara et al. [34] and Ribeiro et al. [18,24], from evaluating the potential of paramonochlorophenol for inducing chromosome aberrations and DNA damage, respectively, did not indicate any potential for genotoxic effects. The induction of DNA damage by iodoform paste revealed in the present study provides support for conducting new investigations and constitutes an initial alert regarding whether it should be indicated.

The results from the present study are in agreement with those of da Silva et al. [6] and Braz et al. [24], who evaluated the genotoxicity of MTA through using the comet assay on human lymphocytes and also did not observe any greater occurrence of DNA damage. This paste has been investigated by several other authors, using the comet assay on other cell types, and except for the results obtained by Naghavi et al. [11], no genotoxic effects were identified in any of them $[6,9,16,24]$. Similar results were showed by Santos et al. [12], using Micronuclei Test.

In the same way as in the present study, no genotoxic effects from calcium hydroxide were identified through the comet assay by Brzovic et al. [25], similarly to results founded by Santos et al. [12] using a different methodology. In the studies by Ribeiro et al. [35,36], the potential of this substance for inducing 
DNA damage was evaluated using the comet assay on lymph cells from mice (L5178Y) and ovary cells from Chinese hamsters (K-1), respectively. In these cell types, too, no greater occurrence of DNA damage was described.

Thus, the results obtained through using the comet assay have revealed that calcium hydroxide does not induce DNA damage. Regarding the potential for calcium hydroxide to induce chromosome damage, Camargo et al. [8] reported a greater occurrence of micronuclei in fibroblasts from Chinese hamsters (lineage V79) that were treated with an endodontic cement based on this substance but which also contained glycyrrhizic acid, methenamine and bisphenol-A. Thus, the genotoxic effects observed could not be attributed in isolation to one of the components of this cement.

From the foregoing, it can be supposed that different biological systems evaluated in the same test and different endpoints evaluated through different methodologies are important factors that lead to conflicting results in evaluating a given product's genotoxicity.

It also has to be taken into consideration that discrepant results may be due to different protocols used for performing the same test. In this context, a few comments are needed in relation to some aspects of the methodology used in the present study. Firstly, the decision to use a single donor to obtain lymphocytes was based on the study by Vijayalaxmi et al. [32] and also on the protocol used in the National Experimental Oncology Laboratory of the Department of Physiology and Pharmacology, Federal University of Ceará, which is the place where the comet assay was developed.

In relation to visual analysis, Wong et al. [31] and Dhawan et al. [37] considered that both types of analysis were valid. According to Collins [38], faithful assessment of the different degrees of DNA damage in accordance with the appearance of the comet does not necessarily require image analysis software, given that the human eye can easily be trained to recognize the characteristics involved. This kind of evaluation was chosen [39,40] and the comet analysis was performed by an experienced blinded investigator in triplicate with coded slides as recommended by Olive and Banáth [21], Hartmann et al. [41] and Wong et al. [31].

\section{Conclusion}

Zinc oxide and iodine paste showed genotoxicity translated with DNA damage according to the comet assay. Calcium hydroxide and mineral trioxide aggregate showed no DNA damage.

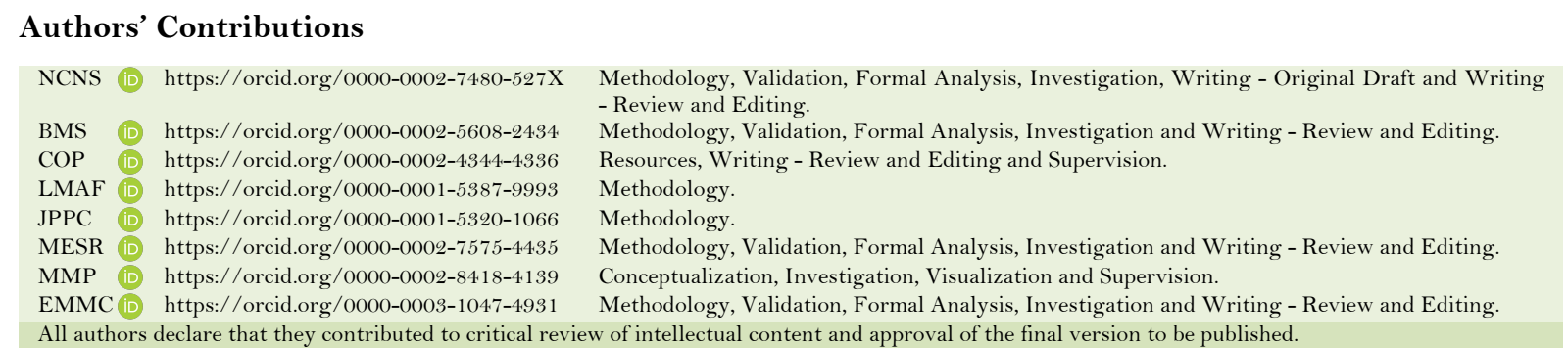

\section{Financial Support}

None.

\section{Conflict of Interest}

The authors declare no conflicts of interest. 


\section{Data Availability}

The data used to support the findings of this study can be made available upon request to the corresponding author.

\section{References}

[1] Pinheiro HHC, Assunção LRS, Torres DKB, Miyahra LAN, Arantes DC. Endodontic therapy in primary teeth by pediatric dentists. Pesqui Bras Odontopediatria Clin Integr 2013; 13(4):351-60. https://doi.org/10.4034/pboci.2013.134.08

[2] Tannure PN, Fidalgo TKS, Barcellos R, Primo LG, Maia LC. Analysis of root canal treated primary incisor after trauma: two-year outcomes. J Clin Pediatr Dent 2012; 36(3):257-62. https://doi.org/10.17796/jcpd.36.3.f8nv08266257v6g4

[3] Massara MLA, Tavares WLF, Noronha JC, Henriques LCF, Ribeiro-Sobrinho AP. Efficacy of calcium hydroxide in the endodontic treatment of primary teeth: six years of follow-up. Pesqui Bras Odontopediatria Clin Integr 2012; 12(2):155-9. https://doi.org/10.4034/PBOCI.2012.122.01

[4] Fuks AB. Vital Pulp Therapy with new materials for primary teeth: new directions and treatment perspectives. J Endod 2008; 34(7s):19s-24s. https://doi.org/10.1016/j.joen.2008.02.031

[5] American Academy of Pediatric Dentistry (AAPD). Guideline on Pulp Therapy for Primary and Immature Permanent Teeth. Pediatr Dent 2016; 38(6):280-8. https://doi.org/10.1016/j.joen.2008.02.031

[6] da Silva GN, Braz MG, de Camargo EA, Salvadori DM, Ribeiro DA. Genotoxicity in primary human peripheral lymphocytes after exposure to regular and white mineral trioxide aggregate. Oral Surg Oral Med Oral Pathol Oral Radiol Endod 2006; 102(5):e50-e54. https://doi.org/10.1016/j.tripleo.2006.02.032

[7] Ramos MESP, Cavalcanti BC, Lotufo LVC, Moraes MO, Cerqueira EMM, Pessoa C. Evaluation of mutagenic effects of formocresol: detection of DNA-protein cross-links and micronucleus in mouse bone marrow. Oral Surg Oral Med Oral Pathol Oral Radiol Endod 2008; 105(3):398-404. https://doi.org/10.1016/j.tripleo.2007.08.009

[8] Camargo CHR, Camargo SEA, Valera MC, Hiller K-A, Schmalz G, Schweikl H. The induction of cytotoxicity, oxidative stress, and genotoxicity by root canal sealers in mammalian cells. Oral Surg Oral Med Oral Pathol Oral Radiol Endod 2009; 108(6):952-60. https://doi.org/10.1016/j.tripleo.2009.07.015

[9] Zeferino EG, Bueno CE, Oyama LM, Ribeiro DA. Ex vivo assessment of genotoxicity and cytotoxicity in murine fibroblasts exposed to white MTA or white Portland cement with 15\% bismuth oxide. Int Endod J 2010; 43(10):8438. https://doi.org/10.1111/j.1365-2591.2010.01747.x

[10] Leite ACGL, Rosenblatt A, Calixto MS, Santos CM, Santos N. Genotoxic effect of formocresol pulp therapy of deciduous teeth. Mutat Res 2012; 747(1):93-7. https://doi.org/10.1016/j.mrgentox.2012.04.006

[11] Naghavi N, Ghoddusi J, Sadeghnia HR, Asadpour E, Asgary S. Genotoxicity and cytotoxicity of mineral trioxide aggregate and calcium enriched mixture cements on L929 mouse fibroblast cells. Dent Mater J 2014; 33(1):64-9. https://doi.org/10.4012/dmj.2013-123

[12] Santos NC, Ramos ME, Ramos AF, Cerqueira AB, Cerqueira EM. Evaluation of the genotoxicity and cytotoxicity of filling pastes used for pulp therapy on deciduous teeth using the micronucleus test on bone marrow from mice (Mus musculus). Mutagenesis 2016; 31(5):589-95. https://doi.org/10.1093/mutage/gew026

[13] Pires CW, Botton G, Cadoná FC, Machado AK, Azzolin VF, da Cruz IB, et al. Induction of cytotoxicity, oxidative stress and genotoxicity by root filling pastes used in primary teeth. Int Endod $\mathrm{J}$ 2016; 49(8):737-45. https://doi.org/10.1111/iej.12502

[14] Mohammadi Z, Shalavi S, Jafarzadeh H, Bhandi S, Patil S. Genotoxicity of endodontic materials: a critical review. J Contemp Dent Pract 2015; 16(8):692-6. https://doi.org/10.5005/jp-journals-10024-1742

[15] Breivik J. The evolutionary origin of genetic instability in cancer development. Sem Cancer Biol 2005; 15(1):51-60. https://doi.org/10.1016/j.semcancer.2004.09.008

[16] Ribeiro DA, Yujra VQ, DE Moura CFG, Handan BA, DE Barros Viana M, Yamauchi LY, et al. Genotoxicity Induced by Dental Materials: A Comprehensive Review. Anticancer Res 2017; 37(8):4017-24. https://doi.org/10.21873/anticanres.11786

[17] Lou J, He J, Sheng W, Jin L, Chen Z, Chen S, et al. Investigating the genetic instability in the peripheral lymphocytes of 36 untreated lung cancer patients with comet assay and micronucleus assay. Mutat Res 2007; 617(1-2):104-10. https://doi.org/10.1016/j.mrfmmm.2007.01.004

[18] Ribeiro DA, Scolastici C, De Lima PL, Marques ME, Salvadori DM. Genotoxicity of antimicrobial endodontic compounds by single cell gel (comet) assay in Chinese hamster ovary (CHO) cells. Oral Surg Oral Med Oral Pathol Oral Radiol Endod 2005; 99(5):637-40. https://doi.org/10.1016/j.tripleo.2004.07.010

[19] Pires CW, Botton G, Cadoná FC, Machado AK, Azzolin VF, da Cruz IB, et al. Induction of cytotoxicity, oxidative stress and genotoxicity by root filling pastes used in primary teeth. Int Endod $\mathrm{J}$ 2016; 49(8):737-45. https://doi.org/10.1111/iej.12502

[20] Singh MP, McCoy M, Tice RR, Schineider P. A simple technique for quantitation of low levels of DNA in individual cells. Exp Cell Res 1988; 175(1):184-91. https://doi.org/10.1016/0014-4827(88)90265-0 
[21] Olive PG, Banáth JP. The comet assay: a method to measure DNA damage in individual cells. Nat Protoc 2006; 1(1):23-9. https://doi.org/10.1038/nprot.2006.5

[22] Burlinson B, Tice RR, Speit G, Agurell E, Brendler-Schwaab SY, Collins AR, et al. Fourth International Workgroup on Genotoxicity testing: Results of the in vivo Comet assay workgroup. Mutat Res 2007; 627(1):31-5. https://doi.org/10.1016/j.mrgentox.2006.08.011

[23] Ribeiro DA, Marques MEA, Salvadori DMF. Antimicrobial endodontic compounds do not modulate alkylationinduced genotoxicity and oxidative stress in vitro. Oral Surg Oral Med Oral Pathol Oral Radiol Endod 2006; 102(2):e32-e36. https://doi.org/10.1016/j.tripleo.2005.11.026

[24] Braz MG, Camargo MG, Salvadori DMF, Marques MEA, Ribeiro DA. Evaluation of genetic damage in human peripheral lymphocytes exposed to mineral trioxide agreggate and Portland cements. J Oral Rehabil 2006; 33(3):2349. https://doi.org/10.1111/j.1365-2842.2005.01559.x

[25] Brzovic V, Miletic I, Zeljezic D, Mladinic M, Kasuba V, Ramic S, et al. In vitro genotoxicity of root canal sealers. Int Endod J 2009; 42(3):253-63. https://doi.org/10.1111/j.1365-2591.2008.01510.x

[26] Guedes-Pinto AC, De Paiva JG, Bozzola JR. Endodontic treatment of deciduous teeth with pulp necrosis. Rev Assoc Paul Cir Dent 1981; 35(3):240-4.

[27] Klaude M, Erikson S, Nygren J, Ahnstrom G. The comet assay: Mechanisms and technical considerations. Mutat Res 1996; 363(2):363-89. https://doi.org/10.1016/0921-8777(95)00063-1

[28] Miyamae Y, Yamamoto M, Sasaki YF, Kobayashi H, Igarashi-Soga M, Shimoi K, et al. Evaluation of a tissue homogenization that isolates nuclei for the in vivo single cell gel electropho-resis (Comet) assay: A collaborative study by five laboratories. Mutat Res 1998; 418(2-3):131-40. https://doi.org/10.1016/S1383-5718(98)00112-0

[29] Lourenço-Neto N, Fernandes AP, Marques NCT, Sakai VT, Moretti ABS, Machado MAAM, et al. Terapia pulpar em dentes decíduos: possibilidades terapêuticas baseadas em evidências. Rev Odontol UNESP 2013; 42(2):130-7. https://doi.org/10.1590/S1807-25772013000200011

[30] Barja-Fidalgo F, Mourinho-Ribeiro M, Oliveira MAA, Oliveira BH. A systematic review of root canal filling materials for deciduous teeth: is there an alternative for zinc oxide-eugenol? ISRN Dent 2011 ; 1:1-7. https://doi.org/ 10.5402/2011/367318

[31] Wong VWC, Szeto YT, Collins AR, Benzie IFF. The comet assay: a biomonitoring tool for nutraceutical research. Curr Top Nutraceutical Res 2005; 3(1):1-14.

[32] Vijayalaxmi V, Tice RR, Strauss GHS. Assessment of radiation-induced DNA damage in human blood lymphocytes using the single-cell gel electrophoresis technique. Mutat Res 1992; 271(3):243-52. https://doi.org/10.1016/0165-1161(92)90019-i

[33] Hikiba H, Watanabe E, Barret JC, Tsutui T. Ability of fourteen chemical agents used in dental practice to indice chromosome aberrations in syrian hamster embryo cells. J Pharmacol Sci 2005; 97(1):146-52. https://doi.org/10.1254/jphs.FPJ04044X

[34] Hagiwara M, Watanabe E, Barret JC, Tsutsui T. Assessment of genotoxicity of 14 chemical agents used in dental practice: ability to induce chromosome aberrations in Syrian hamster embryo cells. Mutat Res 2006; 603(2):111-20. https://doi.org/10.1016/j.mrgentox.2005.08.011

[35] Ribeiro DA, Marques MEA, Salvadori DMF. Lack of genotoxicity of formocresol, paramonochlorofenol, and calcium hydroxide on mammalian cells by comet assay. J Endod 2004; 30(8):593-6. https://doi.org/10.1097/01.don.0000121614.10075.a3

[36] Ribeiro DA, Sugui MM, Matsumoto MA, Duarte MAH, Marques MEA, Salvadori DMF. Genotoxicity and cytotoxicity of mineral trioxide aggregate and regular and white Portland cements on Chinese hamster ovary (CHO) cells in vitro. Oral Surg Oral Med Oral Pathol Oral Radiol Oral Endod 2006; 101(2):258-61. https://doi.org/10.1016/j.tripleo.2005.02.080

[37] Dhawan A, Bajpayee M, Parmar D. Comet assay; a reliable tool for the assessment of DNA damage in diferente models. Cell Biol Toxicol 2009; 25(1):5-32. https://doi.org/10.1007/s10565-008-9072-z

[38] Collins AR. The comet assay for DNA damage and repair: principles, applications, and limitations. Mol Biotechnol 2004; 26(3):249-61. https://doi.org/10.1385/mb:26:3:249.

[39] Logrado LPL, Santos CO, Romeiro LS, Costa AM, Ferreira JR, Cavalcanti BC, et al. Synthesis and cytotoxicity screening of substituted isobenzofuranones designed from anacardic acids. Eur J Med Chem 2010; 45(8):3480-9. https://doi.org/10.1016/j.ejmech.2010.05.015

[40] Paiva JCG, Cabral IO, Soares BM, Sombra CML, Ferreira JRO, Moraes MO, et al. Biomonitoring of ruralworkers exposed to a complex mixture of pesticides in the municipalities of Tianguá and Ubajara (Ceará State, Brazil): Genotoxic and cytogenetic studies. Environ Mol Mutagen 2011; 52(6):492-501. https://doi.org/10.1002/em.20647

[41] Hartmann A, Agurell E, Beevers C, Brendler-Scwaad S, Burlinson B, Clay P, et al. Recommendations for conducting the in vivo alkaline comet assay. Mutagenesis 2003; 18(1):45-51. https://doi.org/10.1093/mutage/18.1.45 